\title{
Impaired lymphocyte reactivity against tumour cells in patients with coeliac disease
}

\author{
B. P. MACLAURIN, W. T. COOKE, AND N. R. LING
}

From the Department of Experimental Pathology, University of Birmingham, and the Birmingham General Hospital

SUMMARY The lymphocytes of patients with coeliac disease are shown to have a significant diminution of proliferative and cytotoxic capacity as compared to normal lymphocytes when challenged in vitro with tumour cells from a lymphoma cell line. This impaired responsiveness is partly related to an intrinsic cellular defect but an inhibiting factor in the serum of coeliac patients has also been demonstrated.

The impaired coeliac lymphocyte response in this in-vitro test system may serve as an indicator of a comparable defect in immune surveillance in vivo. This would account for the increased incidence of lymphosarcoma known to arise in patients with longstanding coeliac disease and might also explain the raised incidence of other gut-related tumours in these patients.

There is an increased incidence of malignant lymphoma and of malignant tumours of the bowel occurring in adult life in patients with coeliac disease (Gough, Read, and Naish, 1962; Austad, Cornes, Gough, McCarthy, and Read, 1967; Harris, Cooke, Thompson, and Waterhouse, 1967). It has also been shown that the lymphocytes of some patients with adult coeliac disease show impaired proliferative capacity on stimulation with the plant mitogen, phytohaemagglutinin (Blecher, Brzechwa-Ajdukiewicz, McCarthy, and Read, 1969), and such lymphocyte cultures show the presence of an unusual number of macrophages (Winter, McCarthy, Read, and Yoffey, 1967). Burnet (1968) has postulated that normal lymphocytes have a 'surveillance function' and are responsible for recognition and elimination of mutant neoplastic cells in the body. Accordingly, it seemed of interest to determine whether the increased incidence of bowel cancer and lymphoma in coeliac disease might be related to impaired lymphocyte function.

Normal lymphocytes show intense proliferation and development of cytotoxic capacity against Burkitt lymphoma cell lines when grown in mixed culture with these tumour cells (Hardy and Ling, 1969; Hardy, Knight, and Ling, 1970; Hardy, Ling, Wallin, and Aviet, 1970). In the present paper it will be demonstrated that lymphocytes from patients with coeliac disease show impaired reactivity against cultured lymphoma cells in both of these parameters. Received for publication 21 July 1971.

\section{Methods}

COEliaC Disease PATIENTS STUdied

All were under the care of W.T.C. and on long-term follow up and supervision. Diagnosis had been established in all cases on the basis of typical small bowel biopsy appearances, coupled with consistent history and laboratory evidence, and absence of malignant disease during the follow-up period. The majority of patients had been receiving a gluten-free diet and various dietary supplements for many years, showed satisfactory nutrition, and were in active employment at the time of study. Details of these cases are presented in Table I.

Control subjects were fit medical students or medical staff who gave no history to suggest bowel disease or recent virus infection. Control cultures were always set up on the same day and under conditions identical to those used for the test cultures. Additional normal subjects were also tested on other occasions, and, since the results were comparable to those of the simultaneous controls, the control group has been enlarged to include these subjects and totals 23 (mean age 28 years).

LYMPHOCYTE CULTURE METHODS EMPLOYED Lymphocyte suspensions were obtained by sedimentation of $20-40 \mathrm{ml}$ of defibrinated blood from each subject, using a $3 \%$ gelatine solution as the sedimentary agent (Coulson and Chalmers, 1964). The lymphocyte-rich supernatant was centrifuged for 


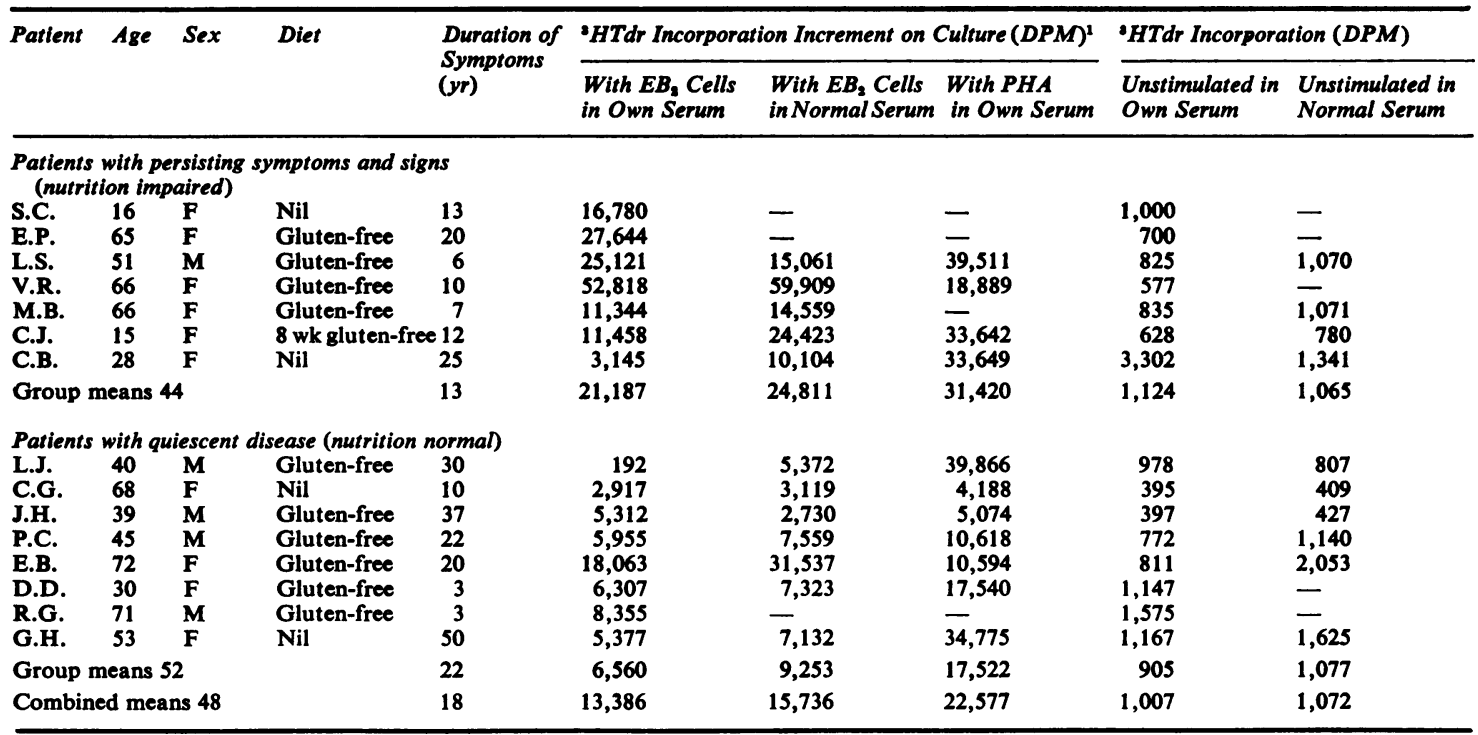

Table I Adult coeliac patients studied

${ }^{1}$ Tritiated thymidine $\left({ }^{3} \mathrm{HTdr}\right)$ incorporation in triplicate in mixed cultures minus the incorporation in triplicate unstimulated control cultures $=$ the incorporation increment_expressed as disintegrations per minute (DPM).

10 minutes at $1,000 \mathrm{rpm}$. The cell deposit was washed twice in Eagles medium and a lymphocyte viability count was performed as determined by trypan blue exclusion. Viable lymphocyte suspensions at $1 \times 10^{6}$ cells $/ \mathrm{ml}$ were prepared in Eagles medium supplemented with $20 \%$ cell-free autologous serum/ gelatine suspension. In the crossed serum experiments, cell suspensions were also prepared with medium supplemented with $20 \%$ fresh control serum/gelatine suspension obtained on the same day. Triplicate $1 \mathrm{ml}$ volumes were dispensed to a series of 3 in. $\times \frac{1}{2}$ in. capped tubes.

For mixed cultures, 200,000 irradiated $(6,000$ r) but viable lymphoma cells from a Burkitt cell line $\left(\mathrm{EB}_{\mathbf{2}}\right)$ maintained in this laboratory, were added in $0.1 \mathrm{ml}$ Eagles medium to triplicate test lymphocyte cultures. Untreated and phytohaemagglutinin (PHA)-treated triplicate cultures served as controls. (The PHA from Burroughs Wellcome, batch no. K.1054 was used at a concentration of $30 \mu \mathrm{g} / \mathrm{ml}$ of culture medium.) All cultures were incubated at $37^{\circ} \mathrm{C}$ in a $5 \% \mathrm{CO}_{2}$ in air mixture. Untreated and mixed cultures were terminated at five days and PHA-treated cultures after three days, with the addition of $0.5 \mu \mathrm{Ci}$ (specific activity $150 \mathrm{mCi} / \mathrm{mM})$ tritiated thymidine $\left({ }^{3} \mathrm{HTdr}\right)$, 24 hours previously in each case. Radioactivity in the trichloracetic acid-insoluble culture fraction (DNA) was counted by a liquid scintillation technique (Knight and Ling, 1969) and used as an index of lymphocyte proliferative response. Subtraction of the disintegrations/minute (DPM) in untreated cultures from the corresponding mixed or PHA-treated test cultures was recorded as the net proliferative response.

\section{CYTOTOXICITY TESTING}

Cytotoxic capacity of unstimulated lymphocytes and of lymphocytes prestimulated for five days with irradiated (unlabelled) EB cells was assessed by the addition of $150,000{ }^{51} \mathrm{Cr}$-labelled EB cells to triplicate test cultures. Radioactivity in the supernatant and in the cell deposit was determined six hours later, and the percentage of total radioactivity in the supernatant was taken to indicate the degree of lymphoma cell destruction. (This is an underestimate since release of label from target cells is only $80 \%$ after total hypotonic lysis.)

The degree of spontaneous release of ${ }^{51} \mathrm{Cr}$ from labelled target cells was assessed from control triplicate series of cultures identical with the test series, except for the absence of the lymphocytes under test. These control values were subtracted from the test values, thus providing a net cytotoxicity percentage. The methods used have been described in greater detail in a previous paper (Hardy et al, 1970). Lymphocytes from a normal subject were always tested in the same manner and on the same day as an additional control. 


\section{Results}

RESPONSE TO EB LYMPHOMA CELLS

The net proliferative response of coeliac lymphocytes to EB lymphoma cells as measured by ${ }^{3} \mathrm{HTdr}$ incorporation into DNA is shown in Table $I$ and compared with the response of normal lymphocytes in Figure 1. An analysis of variance between these two sets of results showed that thymidine incorporation by EB-stimulated coeliac lymphocytes was significantly depressed $(P<0.01)$. Culture of twicewashed, EB-stimulated, coeliac lymphocytes in medium containing normal serum resulted in some improvement for lymphocytes of 10 out of 11 patients so tested, but the overall response was still significantly depressed as compared with the normal lymphocyte results. This suggested that the impaired response by coeliac lymphocytes was partly attributable to a cellular defect. However, comparison of EB responses by coeliac lymphocytes in normal serum with the response of normal lymphocytes in coeliac serum (Fig. 2) then showed no significant difference $(0.2<P>0.1)$, thus proving that there was also a depressant serum factor operating.

\section{RESPONSE TO PHA}

The net proliferative response of coeliac lymphocytes to PHA (Table I and Fig. 3) was also depressed as compared with the lymphocyte response of control subjects, but with the smaller number tested in this way the degree of depression did not reach statistical significance. As with EB stimulation, depression of

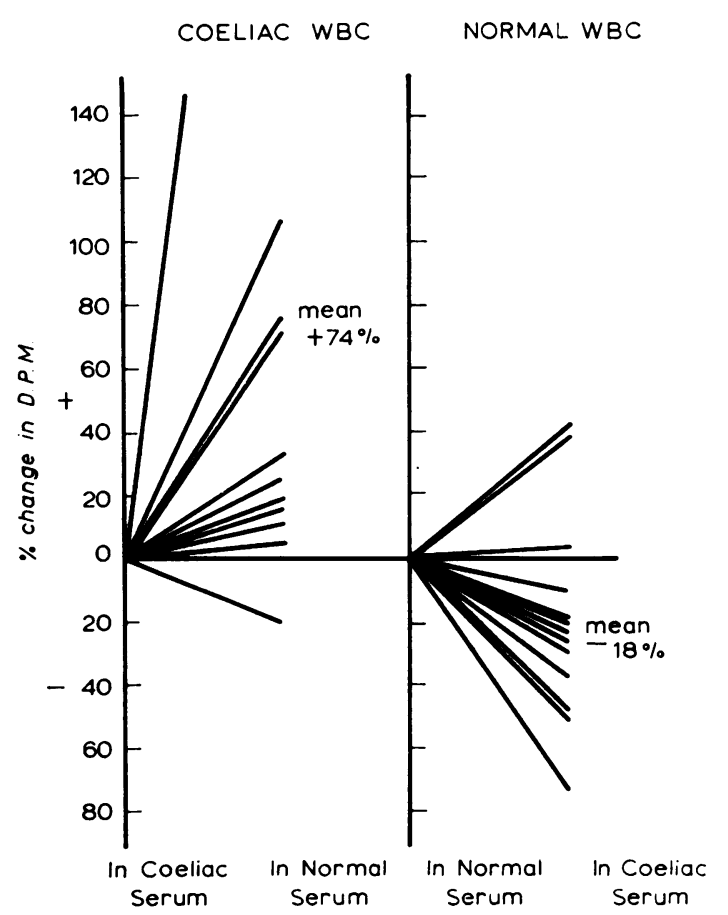

Fig. 2.

Fig. 1 Comparison of proliferative response to lymphoma cells $\left(E B_{2}\right)$ by coeliac lymphocytes and by normal lymphocytes (measured by ${ }^{3} \mathrm{HTdr}$ incorporation into DNA).

Fig. 2 Comparison of proliferative response to $\mathbf{E B}_{2}$ cells by lymphocytes grown in medium supplemented with normal serum or with coeliac serum. 
the PHA response was most marked in the inactive patients, but a separate analysis of this subgroup also failed to reach significance $(P<0.2>0 \cdot 1)$.

\section{${ }^{3}$ HTdr INCORPORATION BY UNSTIMULATED LYMPHOCYTES}

Further evidence for the presence of a depressant serum factor in patients with coeliac disease was obtained by comparing the degrae of tritiated thymidine incorporation in unstimulated control cultures of patients and of normal subjects. Figure 4 illustrates this comparison and an analysis of variance showed a possibly significant depression in unstimulated thymidine incorporation by coeliac lymphocytes $(P<0 \cdot 1)$. There was a mild improvement in incorporation for eight of 10 subjects studied when coeliac lymphocytes were grown in medium containing normal serum. Furthermore, when normal lymphocytes were grown in medium containing coeliac serum, thymidine incorporation was

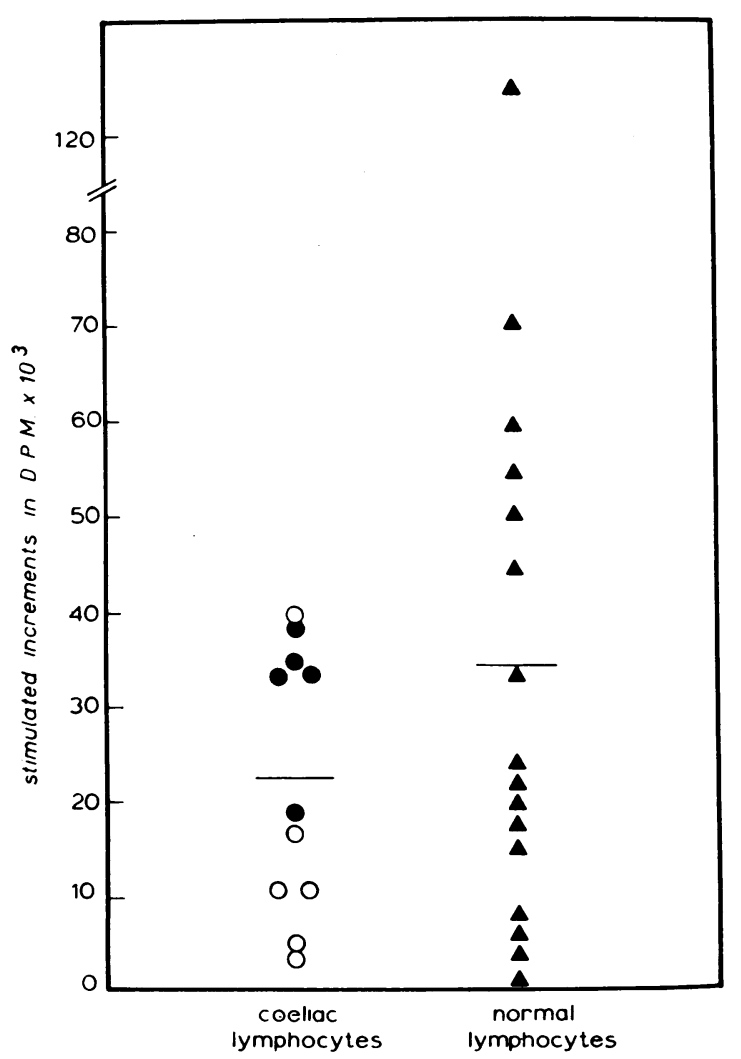

Fig. 3 Comparison of proliferative response to $\mathrm{PHA}$ by coeliac lymphocytes and by normal lymphocytes. ( ${ }^{3}$ HTdr incorporation into DNA.) depressed (eight of 10 subjects). Comparison of these results with those for coeliac lymphocytes in normal serum and medium then showed no significant difference $(P>0 \cdot 2)$. No evidence was obtained to suggest that the coeliac serum was directly cytotoxic and lymphocyte viabilities at the end of the five-day culture period were approximately the same for coeliac and normal lymphocytes grown in either coeliac or normal serum.

Rather surprisingly in the light of the above findings, coeliac lymphocytes stimulated by PHA showed a somewhat greater depression of response when grown in normal serum than when grown in coeliac serum.

CYTOTOXICITY

The results of coeliac lymphocyte cytotoxicity tests on ${ }^{51} \mathrm{Cr}$-labelled EB lymphoma cells, added on the fifth day of culture, are shown in Fig. 5 and compared with the mean of the results obtained with lympho-

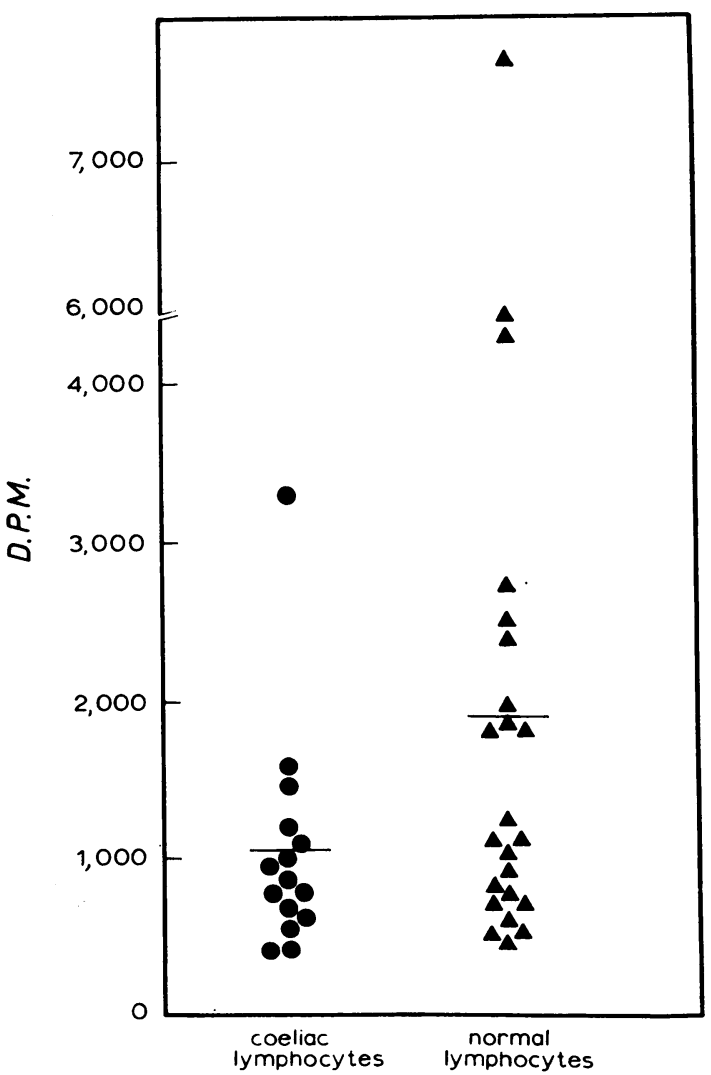

Fig. 4 A comparison of ${ }^{3} H T d r$ incorporation into $D N A$ by unstimulated lymphocytes on the fifth day of culture. 
cytes from 11 normal subjects. The net cytotoxicity of unstimulated coeliac lymphocytes cultured for five days was moderately depressed with a mean of $7 \%$ as compared to a mean of $13 \%$ for 11 normal control subjects, but an analysis of variance failed to show statistical significance $(P=0 \cdot 2)$. However, comparison of the cytotoxicity of coeliac lymphocytes prestimulated for five days with irradiated unlabelled EB cells and then tested with ${ }^{51} \mathrm{Cr}$-labelled EB cells showed a significant depression of cytotoxicity (mean 13\%) as compared to similarly treated normal lymphocytes (mean $32 \%)(P<0.05)$.
These results illustrate the relative failure of coeliac lymphocytes 'immunized' in vitro to develop increased cytotoxic capacity in comparison with the well marked accentuation of normal lymphocyte cytotoxicity under similar conditions.

The EB lymphoma line used has previously been shown to be positive for EB virus (three years ago) but more recent testing has suggested that this is no longer the case. Nonetheless, it seemed possible that impaired coeliac lymphocyte proliferative and cytotoxic response to $\mathrm{EB}$ cells might relate to increased levels of EB virus antibody in coeliac

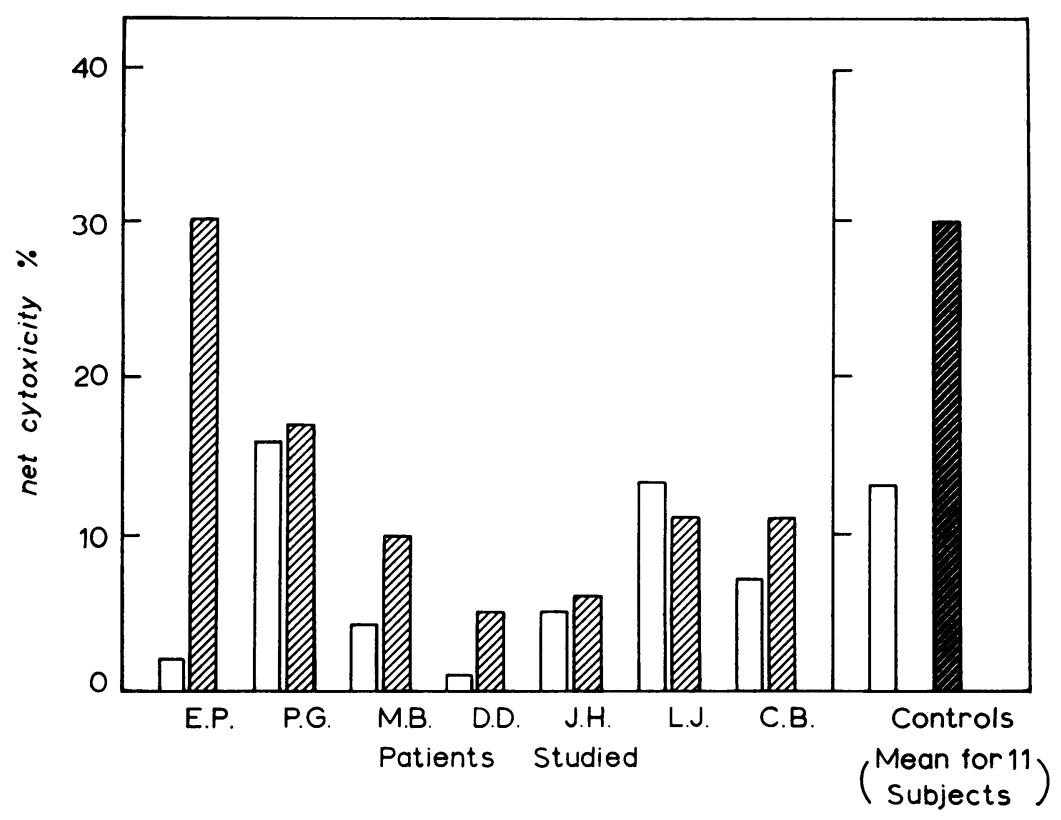

Fig. 5 Comparison of net cytotoxicity of coeliac or normal lymphocytes upon ${ }^{51}$ Cr-labelled $E B_{2}$ cells over a six-hour period. Net cytotoxicity $=\%{ }^{51} \mathrm{Cr}$ release in test culture with lymphocytes - spontaneous release of label in parallel culture identical except for the absence of lymphocytes. (Mean spontaneous release of label was 16\%. Range 11-21.) Open columns represent unstimulated lymphocyte results. Hatched columns indicate lymphocytes prestimulated with irradiated EB cells.

\begin{tabular}{|c|c|c|c|c|c|c|c|c|c|c|c|}
\hline \multirow[t]{3}{*}{ Patient } & \multirow[t]{3}{*}{$\begin{array}{l}\text { Age } \\
\text { (mth) }\end{array}$} & \multirow[t]{3}{*}{$\operatorname{Sex}$} & \multirow[t]{3}{*}{ Diet } & \multirow{3}{*}{$\begin{array}{l}\text { Duration of } \\
\text { Symptoms } \\
\text { (mth) }\end{array}$} & \multicolumn{5}{|c|}{ Lymphocytes from Coeliac Patients } & \multirow{2}{*}{\multicolumn{2}{|c|}{$\begin{array}{l}\text { Lymphocytes from } \\
\text { Normal Controls } \\
\text { 'HTdr Incorporation } \\
(D P M)\end{array}$}} \\
\hline & & & & & \multicolumn{3}{|c|}{$\begin{array}{l}{ }^{3} \text { HTdr Incorporation Increment on } \\
\text { Culture }(D P M)^{1}\end{array}$} & \multicolumn{2}{|c|}{$\begin{array}{l}\text { 'HTdr Incorporation } \\
(D P M)\end{array}$} & & \\
\hline & & & & & $\begin{array}{l}\text { With } E B_{2} \\
\text { Cells in } \\
\text { Own Serum }\end{array}$ & $\begin{array}{l}\text { With EB, } \\
\text { Cells in } \\
\text { Normal } \\
\text { Serum }\end{array}$ & $\begin{array}{l}\text { With PHA } \\
\text { in Own } \\
\text { Serum }\end{array}$ & $\begin{array}{l}\text { Unstimul- } \\
\text { lated in } \\
\text { Own } \\
\text { Serum }\end{array}$ & $\begin{array}{l}\text { Unstimu- } \\
\text { lated in } \\
\text { Normal } \\
\text { Serum }\end{array}$ & $\begin{array}{l}\text { Unstimu- } \\
\text { lated in } \\
\text { Own } \\
\text { Serum }\end{array}$ & $\begin{array}{l}\text { Unstimu- } \\
\text { lated in } \\
\text { Coeliac } \\
\text { Serum }\end{array}$ \\
\hline \multicolumn{12}{|c|}{ With active (untreated) disease } \\
\hline H.K. & 17 & $\mathbf{F}$ & Nil & 6 & 16,450 & 20,774 & - & 732 & 800 & 851 & 552 \\
\hline F.W. & 6 & F & Nil & 2 & 9,131 & 18,404 & - & 480 & 1,463 & 851 & 313 \\
\hline T.J. & 14 & $\mathbf{F}$ & Nil & 3 & 7,272 & 9,352 & 25,005 & 423 & 901 & 851 & 460 \\
\hline \multicolumn{12}{|c|}{ With inactive (treated) disease } \\
\hline & 24 & & Gluten-free 9/12 & Nil for $12 / 12$ & 3,570 & 6,150 & 11,100 & 284 & 564 & 851 & 420 \\
\hline M.C. & 17 & $\mathbf{M}$ & Gluten-free $6 / 12$ & Nil for $7 / 12$ & 21,123 & 22,312 & 31,524 & 915 & 731 & 2,024 & 965 \\
\hline M.D. & 60 & $\mathbf{M}$ & Gluten-free $48 / 12$ & Nil for $48 / 12$ & 16,245 & 16,460 & 24,522 & 550 & - & 2,024 & 823 \\
\hline
\end{tabular}

Table II Children with coeliac disease studied

${ }^{1}$ Tritiated thymidine ( $\left.{ }^{3} \mathrm{HTdr}\right)$ incorporation in triplicate in mixed cultures minus the incorporation in triplicate unstimulated control cultures $=$ the incorporation increment expressed as disint egrations per minute (DPM). 
serum as compared to normal serum. Samples of serum from 10 coeliac subjects were kindly tested for EBV antibodies by Dr G. Henle of Philadelphia, USA, but the results did not differ significantly from those expected for populations of comparable age and sex.

\section{RESPONSES IN INFANCY AND CHILDHOOD}

A preliminary assessment of the proliferative response to $\mathrm{EB}_{2}$ stimulation of lymphocytes from coeliac subjects in infancy and early childhood has been undertaken by courtesy of Professor Charlotte Anderson and her staff at the Children's Hospital, Birmingham. The results are shown in Table II. The lymphocytes of two treated children appeared to show relatively normal responses compared with the adult control values, and there was little difference on culture in normal serum compared with coeliac serum. However, lymphocyte responses of three other infants (two untreated and one treated) were markedly depressed, and in the range found with inactive adult coeliac disease. In these subjects a depressant serum factor was also demonstrated.

\section{Discussion}

The impaired proliferative and cytotoxic response of adult coeliac lymphocytes stimulated by EB lymphoma cells provides a new parameter for investigation of the nature and significance of the immune defect in this disease. It will be noted from Table I that the impaired response to EB cells and to phytohaemagglutinin was most marked in those patients having inactive disease and therefore seems unlikely to be due to nutritional deficiency. This group of patients was somewhat older (mean age 52) in comparison with the active group (mean age 44) and had more longstanding disease (mean duration 22 years compared with 13 years). Restricting dietary gluten for adult patients did not appear to influence the lymphocyte proliferative response to either stimulus. The nature of the depressant factor in serum demonstrated has not been established, but is currently being actively studied.

The failure to show a statistically significant reduction in lymphocyte response to PHA for the whole coeliac series may relate to differences in the ratio of active and inactive, and disease of short and long duration, compared with previously reported studies (Winter et al, 1967; Blecher et al, 1969). In any case, statistical analysis of this kind was not carried out by these authors.

The association of diminished lymphocyte reaction to EB cells and probably to PHA occurring in some children as well as in adults with coeliac disease, but not seen with lymphocytes from normal cord blood
(Hardy et al, 1970), suggests a rather broad defect in cellular immune response. This defect may primarily involve the thymus-dependent lymphocyte population since both the mixed lymphocyte reaction and the capacity for PHA response are known to be thymus dependent (Wilson, Silvers, and Nowell, 1967; Iversen, 1969). Virus infection in the prenatal or neonatal period is associated with impaired immunity of this type, eg, the immune defect in neonatal rubella infection (Dent, Olson, Good, Rawls, South, and Melnick, 1968), and might possibly provide an explanation for the immune defect in coeliac disease.

The reaction of normal lymphocytes to lymphoma cell lines in mixed culture appears to be a special form of the mixed lymphocyte reaction. The intensity of this reaction is known to be partly related to the degree of HL-A antigenic disparity of the participating cells (Steel and Hardy, 1970), but might also serve to predict the likely fate of lymphoma cells appearing in a particular subject. It is noteworthy that a proliferative response can still be elicited for normal lymphocytes stimulated by an autologous lymphoid cell line derived one year previously (Steel and Hardy, 1970), a situation presumably analogous to that resulting from spontaneous lymphoid tumour cell mutation. If there is a general reduction in the number or functional capacity of thymus-derived lymphocytes in patients with longstanding coeliac disease, and if Burnet's views on lymphocyte immune surveillance are accepted, then the increased frequency of other types of gut-related tumours in coeliac disease may also be explained. The known high cell turnover rates in the gut epithelium will be increased at least for the small bowel, in untreated or partially gluten-restricted patients (Croft, Loehry, and Creamer, 1968) with consequent increased possibilities for tumour cell mutation at mitosis. Impaired lymphocyte stimulation and cytotoxic capacity against such tumour cell deviants might then result in overt tumour development.

B.P.M. was supported by a Nuffield Foundation travelling fellowship in medicine while on sabbatical leave from the University of Otago Medical School, New Zealand. We are grateful to Mrs Francis Levy and Miss Barbara Newey for technical assistance. Professor Charlotte Anderson, Dr McNeish, and Dr Challacombe of the Birmingham Children's Hospital were most generous in providing access to coeliac patients under their care and making blood specimens and case notes available for this study. The help of Dr George Klein of the Karolinska Institute, Stockholm, and $\mathrm{Dr}$ G. Henle of the Children's Hospital, Philadelphia, in the performance 
and interpretation of EBV antibody titres on coeliac sera is gratefully acknowledged. $\mathrm{Mr} \mathrm{J}$. Vaughan-Smith of the Department of Experimental Pathology provided assistance in the statistical analysis of the data. This work was presented at a meeting of the British Society for Immunology in October 1970.

Requests for reprints should be addressed to B.P.M. at the Department of Medicine (Wellcome Institute), University of Otago Medical School, Dunedin, New Zealand.

\section{References}

Austad, W. I., Cornes, J. S., Gough, K. R., McCarthy, C. F., and Read, A. E. (1967). Steatorrhea and malignant lymphoma. Amer. J. dig. Dis., 12, 475-490.

Blecher, T. E., Brzechwa-Ajdukiewicz, A., McCarthy, C. F., and Read, A. E. (1969). Serum immunoglobulins and lymphocyte transformation studies in coeliac disease. Gut, 10, 57-62.

Burnet, F. M. (1968). A modern basis for pathology. Lancet, 1, 1383-1387.

Coulson, A. S., and Chalmers, D. G. (1964). Separation of viable lymphocytes from human blood. Lancet, 1, 468-469.

Croft, D. N., Loehry, C. A., and Creamer, B. (1968). Small-bowel cell-loss and weight loss in the coeliac syndrome. Lancet, 2, 68-70.

Dent, P. B., Olson, G. B., Good, R. A., Rawls, W. E., South, M. A. and Melnick, J. L. (1968). Rubella-virus leucocyte interaction and its role in the pathogenesis of the congenital rubella syndrome. Lancet, 1, 291-293.

Gough, K. R., Read, A. E., and Naish, J. M. (1962). Intestinal reticulosis as a complication of idiopathic steatorrhoea. Gut, 3, 232-239.

Hardy, D. A., Knight, S., and Ling, N. R. (1970). The interaction of normal lymphocytes and cells from lymphoid cell lines. I. The nature of the activation process. Immunology, 19, 329-342.

Hardy, D. A., and Ling, N. R. (1969). Effects of some cellular antigens on lymphocytes and the nature of the mixed lymphocyte reaction. Nature (Lond.), 221, 545-548.

Hardy, D. A., Ling, N. R., Wallin, J., and Aviet, T. (1970). Destruction of lymphoid cells by activated human lymphocytes. Nature (Lond.), 227, 723-725.

Harris, O. D., Cooke, W. T., Thompson, H., and Waterhouse, J. A. H. (1967). Malignancy in adult coeliac disease and idiopathic steatorrhoea. Amer. J. Med., 42, 899-912.

Iversen, J. G. (1969). Phytohemagglutinin response of recirculating and non-recirculating rat lymphocytes. Exp. Cell Res., 56, 219-223.

Knight, S., and Ling, N. R. (1969). A comparison of the responses of lymphocytes from blood, spleen, thymus and appendix of rabbits of different ages to stimulation 'in vitro' with staphylococcal filtrate. Clin. exp. Immunol., 4, 667-684.

Steel, C. M., and Hardy, D. A. (1970). Evidence of altered antigenicity in cultured lymphoid cells from patients with infectious mononucleosis. Lancet, 1, 1322-1323.

Wilson, D. B., Silvers, W. K., and Nowell, P. C. (1967). Quantitative studies on the mixed lymphocyte interaction in rats. II. Relationship of the proliferative response to the immunologic status of the donors. J. exp. Med., 126, 655-665.

Winter, G. C. B., McCarthy, C. F., Read, A. E., and Yoffey, J. M. (1967). Development of macrophages in phytohaemagglutinin cultures of blood from patients with idiopathic steatorrhoea and with cirrhosis. Brit. J. exp. Path., 48, 66-80. 